\title{
ANALYSIS OF THE DEVELOPMENT AND IMPORTANCE OF AGRITOURISM THROUGH THE PERCEPTION OF THE LOCAL POPULATION IN MIDDLE BANAT
}

Generally tourism as a business has never had an enviable position on the market in comparison to other branches of the economy. Serbia is a country of rural space, but this form of tourism is not in the expansion. A poor economic and political situation in the last years of the 20th century contributed to a large extent to the bad condition of tourist activity. The authors of the paper conducted a field research in the area of Middle Banat in order to discover the perception of the local population about the significance of the development of this activity. The survey was conducted in May 2017 in five municipalities of Middle Banat, and the results clearly indicate the respondents' lack of awareness of the significance of the development of agritourism, although there are real preconditions for the massive development of this activity. Residents recognize the range of positive and negative effects of tourism development, but the degree to which they are willing to tolerate negative effects depends on their involvement in tourism, the length of their stay in the destination and their exposure to tourism traffic in everyday life.

Keywords: agritourism, local population, sustainable development, Middle Bana

* Novi Sad Business School, Serbia; mmrksa@gmail.com

** Novi Sad Business School, Serbia; tamara.gajic.1977@gmail.com

*** Novi Sad Business School, South Ural State University, Institute of Sports, Tourism and Service, Chelyabinsk, Russia; aleksandravujko@yahoo.com 


\section{Introduction}

Middle Banat, as a territorial unit of Serbia, has never enjoyed the position of a highly developed tourist area, nor has it had an adequate promotion on the European and World tourist market. The conditions for the development of the agro-tourism product certainly exist and some of them include cultural and historical heritage, gastronomy, tourist-geographical position, ethnic heterogeneity, etc. In these parts of Serbia agriculture is the primary activity in every sense of the word. Agritourism, although a major driver of other economic sectors in the World, and in Middle Banat, is on an unsettled position, primarily because of the lack of interest of key stake holders, as well as the absence of the state and other subjects' investments ${ }^{1}$. For the development of tourism, it is the harmonization of planned and strategic development with the requirements and needs of the local population that comes in the first place. Where there is no support from the local population, there is no point discussing mass tourism movements. The local population is involved in tourism in different ways. Some participate directly in tourism (providing catering services), some indirectly (by selling certain products related to tourism), while others do not participate in tourism in general. Local communities should have a significant share in projects related to the implementation of tourism in their communities. Even if local residents work somewhere else, they should have an important role in the tourist activity of the local environment ${ }^{2}$.

Also, they may feel unsatisfied about their environment, unless they recognize certain negative elements in their place. Therefore, social and economic cohesion at the local level are the key supporting factors necessary for success in local tourism development. The authors of the paper examined the attitude of the local population about the development of tourism in the municipalities of Middle Banat: Zrenjanin, Nova Crnja, Žitište, Novi Bečej, Sečanj. Having studied secondary documentation and papers on a similar topic, the authors set up certain hypotheses in their research and analyzed the results of very poor state of awareness of the local population of the development of agritourism and its impact on the entire environment. The analysis was processed in relation to some of the basic demographic characteristics of the population; the SPSS software system was used, version 23.0.

Vujko, A., Petrović, M., Dragosavac, M., Gajić, T., (2016): Differences and similarities among rural tourism in Slovenia and Serbia - perceptions of local tourism workers, Ekonomika poljoprivrede, 4/2016, 1463.

2 Gajić, T. (2010): Tourism in the function of intensification receptive and emissive regions example of South Bačka region, Industry, 38(3), 147. 


\section{Background of the study and hypothesis setting}

\subsection{Agritourism in Europe and Serbia}

Agritourism supports various activities which are based on natural and cultural values for local communities, enabling the original experiences of tourists. Some theorists believe that agritourism is an alternative example that serves as a form of tourism that is in accordance with natural and social values and which helps domestic and foreign guests to enjoy the positive and valuable interaction and exchange of experiences. Many researches point out segments involving mining tourism, and most often it is said that this form of tourism possesses a wide range of attractions and activities that usually relate to a more favorable or non-urban environment. The significance of agritourism is reflected in the impact of socioeconomic revitalization. According to some authors ${ }^{3}$, rural tourism in both developed and underdeveloped countries often serves to foster regional economic activities. They ${ }^{4}$ point out that tourists capture rural areas as places of security surrounded by open spaces and natural beauties, where everyone is treated with respect and courtesy. Certainly, rural tourism contributes to economic development of the country and brings additional benefits. In principle, rural tourist destinations essentially have different characteristics: wide open spaces, a low level of tourism development and opportunities for visitors to experience a more favorable and/or natural center directly. According to some authors, ${ }^{5}$ there are about 200,000 renowned service providers in Europe's rural tourism with more than two million beds. In small family pensions and hotels, a direct annual tourist consumption of about 12 billion Euros has been realized. The development of agrotourism in Serbia is incomplete and insufficiently heterogeneous due to the non-synchronized and unorganized supply, as well as the lack of interest of main entities for investing in the development of this type of tourist product.

3 Petrović, M., Blešić, I., Vujko, A., Gajić, T. (2017). The role of agrotourism impact in local community in a transition society - a report from Serbia. Transylvanian Review of Administrative Structure Sciences, 50(1), 158.

$4 \quad$ Vujko, A., Gajić, T. (2014): Opportunities for tourism development and cooperation in the region by improving quality supply - The Cycle Danube Route - Case study, Economic Research, 27(1), 851.

5 Petrović, M., Blešić, I., Vujko, A., Gajić, T. (2017): The role of agrotourism impact in local community in a transition society - a report from Serbia, Transylvanian Review of Administrative Structure Sciences, 50(1), 154. 
Table 1. The average number of overnight stays ( $d$-domestic; $f$-foreign)

\begin{tabular}{|c|c|c|c|c|c|c|c|c|c|}
\hline \multicolumn{2}{|l|}{ Year } & Serbia & Vojvodina & $\begin{array}{c}\text { Middle } \\
\text { Banat }\end{array}$ & Zrenjanin & Žitište & $\begin{array}{c}\text { Nova } \\
\text { Crnja }\end{array}$ & $\begin{array}{c}\text { Novi } \\
\text { Bečej }\end{array}$ & Sečanj \\
\hline \multirow{2}{*}{2005} & d & 3,6 & 3,1 & 3,3 & 3,1 & 4,8 & 2,4 & 3,7 & - \\
\cline { 2 - 10 } & f & 2,2 & 2,2 & 2,5 & 2,5 & 1,9 & 2,8 & 2,9 & - \\
\hline \multirow{2}{*}{2010} & d & 3,8 & 3,2 & 4,1 & 4,2 & 4,2 & 3,9 & 3,7 & 4,8 \\
\cline { 2 - 10 } & f & 2,1 & 2,1 & 2,8 & 2,9 & 1,4 & 1,6 & 2,4 & 2,1 \\
\hline \multirow{2}{*}{2015} & d & 3,3 & 2,6 & 3,4 & 3,6 & 3,0 & 2,4 & 2,7 & 3,7 \\
\cline { 2 - 10 } & f & 2,1 & 2,2 & 3,8 & 3,9 & 2,1 & 2,0 & 3,2 & 2,6 \\
\hline
\end{tabular}

Source: author's calculations based on statistical data of the Statistical Office of the Republic of Serbia.

Rural area affects about $85 \%$ of Serbia where around $43 \%$ of the total population lives. As for the participation of rural population in the total population of Serbia according to the areas of the state, the situation is as follows: Vojvodina has about $44.62 \%$ of rural population, Central Serbia $42.40 \%$, Belgrade area $18.9 \%$, other areas $55.4 \%$. Compared to the data from 2006, when 140 households were recorded in 44 villages, with 750 beds, in 2014 the data increased significantly, when rural tourism was realized in 119 villages, 164 households and 1,628 beds. On average, there are 408,580 overnight stays in rural tourism in Serbia. Domestic visitors make up almost $90 \%$ of all visitors in rural tourism in Serbia. Statistical data from 2011 show that demographic trends in Serbia, especially in the southern rural area, are becoming increasingly unfavorable. In the period from 2002 to 2011, there was a decline in the rural population by 311,139 inhabitants $(10.9 \%)^{6}$.

According to the research goal, the hypothesis $\mathrm{H} 0$ has been set up: there is a significant statistical difference in the perception of the population of the development and importance of tourism in relation to demographic segments (gender, age, education).

\subsection{Perception of the local population of the positive and negative effect of tourism development and sustainable development}

The survey of attitudes of the local population is of key importance for the development of tourist activity in a certain destination. Most theorists who deal with this current topic emphasize the positive effects of tourism development.

$6 \quad$ Vujko, A., Petrović, M., Dragosavac, M., Gajić, T., (2016): Differences and similarities among rural tourism in Slovenia and Serbia - perceptions of local tourism workers, Ekonomika poljoprivrede, 4/2016, 1463. 
However, when tourism becomes a mass phenomenon, it usually implies negative effects on the entire system and society according to the residents' opinions. Many theorists have noted that individuals begin to get involved more in the tourism industry when they see positive effects of its development, where resource trade has more benefits than costs. Also, an increased involvement of the local population in the development of tourism reflects positive effects. Some authors focus on the positive and negative effects of tourism trends in the development of local communities and the perception of the local population ${ }^{7,8,9}$. A recent research on the perceptions of tourism development is based exclusively on the emphasis on the benefits of this economic activity, which raises the quality of life of the local population. Seasonal character is the highest possible negative impact on local population. Negative attitudes of the local population can slow down the development of tourism and lead to stagnation in tourist destinations as well as cause negative effects on local attractions and the hospitality of local residents. On the other hand, it is exactly the local attractions and hospitality of local residents that success of the tourism industry depends on. Knowing that the relationship to tourism of the local population helps to reduce the negative effects and costs, on the one hand, it leads to the positive development of this industry, on the other. The research interest in the population attitudes towards tourism started in developed countries, especially in the United States of America ${ }^{10,}{ }^{11}$, and in the areas and countries where tourism develops intensively, such as New Zealand, Canada, Australia and the United Kingdom ${ }^{12}$. Other studies were conducted mainly due to the fact that half of the population can play a decisive role in creating a positive or negative attitude towards tourism, contributing

Tosun, C. (2006): Expected nature of community participation in tourism development. Tourism Management, 27(3), 499.

8 Almeida, F., Balbuena, A., Corte s, R. (2015): Residents' attitudes towards the impacts of tourism, Tourism Management Perspectives, 13(1), 37.

9 Chen, F., Tian, L., (2015): Comparative study on residents' perceptions of follow-up impacts of the 2008 Olympics, Tourism Management, 51, 270.

10 Huh, C., Vogt, C. A. (2008): Changes in residents' attitudes toward tourism over time: a cohort analytical approach, Journal of Travel Research, 46, 451.

11 Kim, K., Uysal, M., Sirgy, M. (2013): How does tourism in a community impact the quality of life of community residents? Tourism Management, 36, 533.

12 Woods, N. (2003): The United States and the international financial institutions. In R. Foot, N. MacFarlane, \& M. Mastanduno (Eds.), US hegemony and international organizations (pp. 92-114). Oxford: Oxford University Press. 
thus to its development ${ }^{13,14,15}$. Huh and $\operatorname{Vog}^{16}$ came to a similar conclusion and pointed out that middle-aged hosts had more negative attitudes towards tourism development than the younger generation. In fact, citizens' attitudes toward tourism are gradually improving with an increase in the level of education. Young generations do not have real power or control over the decision-making process $^{17}$. On the other hand, local people have great power in determining the development of the tourism industry, but this can manifest very spontaneously. The cooperation between local institutions and their members contributes to the positive development of joint decision-making and setting goals, but the advantages of all this can be individual ${ }^{18,}{ }^{19}$. However, some authors point out that local population has little or significant influence on decision making and the direction of the development of some tourist destinations ${ }^{20}$. The decisions and attitudes of the local population are partially limited by the political and economic conditions in which the destination is located, which can hinder or facilitate the creation of a development program by the local population ${ }^{21}$. Like other industries, tourism affects the quality of the environment, as a consumer of natural and other resources: land, water, fuel, electricity and food. In addition, it also produces significant amounts of waste and emissions. The negative impact of tourism on the environment is expressed through pressure on natural resources, the living world and habitats, and the creation of waste and pollution. Yet, tourism has a great interest to maintain the quality of the environment at a high level, with clean and healthy environment being a very important assumption of its successful development. The positive effects of tourism in relation to the environment are reflected in the fact that this is an activity that strives for the

13 Mason, P., Cheyne, J. (2000): Residents attitudes to proposed tourism development, Annals of Tourism Research, 27(2), 410.

14 Balaguer, J., Cantavella-Jorda, M. (2002): Tourism as a longrun economic growth factor the Spanish case, Applied Economics, 34(7), 885.

15 Zhang, Y., Cole, S. T., Chancellor, C. H. (2013): Residents' preferences for involvement in tourism development and influences from individual profiles, Tourism Planning \& Development, 10(3), 270.

16 Huh, C., Vogt, C. A. (2008): Changes in residents' attitudes toward tourism over time: a cohort analytical approach, Journal of Travel Research, 46, 449.

17 Gursoy, D., Jurowski, C., Uysal, M. (2002): Resident attitudes. A structural modeling approach, Annals of Tourism Research, 29(1), 99.

18 Ko, D. W., Stewart, W. P. (2002): A structural equation model of residents' attitudes for tourism development, Tourism Management, 23, 525.

19 Farmaki, A., Altinay, L., Botterill, D., Hilke, S. (2015): Politics and sustainable tourism: The case of Cyprus, Tourism Management, 47, 188.

20 Nunkoo, R., Gursoy, D. (2012): Residents' support for tourism an identity perspective, Annals of Tourism Research, 39(1), 255.

$21 \quad$ Prayag, G., Hosany, S., Nunkoo, R., Alders, T. (2013): London residents' support for the 2012 Olympic games: the mediating effect of overall attitude, Tourism Management, 36, 635. 
adequate use of natural resources, the improvement of the landscape and the maintenance of the ecological, economic and socio-cultural values of the local community. The simplest definition is that "sustainable tourism implies every form of tourism that contributes to the protection of the environment, social and economic integrity and the promotion of natural, created and cultural values on a sustainable basis"22. In order to achieve the development of sustainable tourism, an integrated approach to its planning along with management is necessary. Under no circumstances does sustainable development aim to stop the development of tourism; it aims to enable its development in a way that tourists see and experience what they want, but without destroying the very factors that have attracted them. At the same time, the society, culture and environment of people living in tourist destinations are not destroyed or endangered ${ }^{23}$. The tourism industry should communicate with local communities and involve them in its development. Tourism, with its position in the world economy, has a moral responsibility to take the lead in achieving a transition to sustainable development. It has its own interest in it. This sector is not only expanding, but the way tourists travel is also changing. The rising trend is that people go on shorter holidays and travel further from their homes. It was estimated that in 2000, almost 150 million tourists (domestic and foreign) visited the Mediterranean coast, doubling the number of inhabitants. Natural resources and local infrastructure are often in conflict with a drastic increase in the number of people during the tourist season. The construction of hotels and associated infrastructure represents a huge blow to drinking water supplies, land use and ecosystems. Hotels are large water consumers. The average tourist consumes up to 200 liters, while tourists in luxurious accommodation spend up to 700 liters of water per day ${ }^{24}$. When they are on holiday, tourists spend a lot of energy, water and produce much more waste. More and more Europeans build cottages in which they do not spend much time, occupying much more land than any other type of accommodation. It is important that further development of tourist sites is limited and in line with local resources such as water, land surface, untouched nature and social acceptance of the local population. The hypotheses related to the part of the research dealing with the influence of agro tourism, as well as the significance of sustainability in tourism development, are as follows:

H1 - Agrotourism has not been developed sufficiently.

$\mathrm{H} 2$ - Agrotourism represents a developmental opportunity in the investigated municipalities.

\footnotetext{
$22 \quad$ Andriotis, K., (2006): Hosts, Guests and Politics, Annals of Tourism Research, 33(4), 1089.

23 Waligo, V. M., Clarke, J., Hawkins, R. (2013): Implementing sustainable tourism: A multistakeholder involvement management framework, Tourism Management, 36, 444.

24 Farmaki, A., Altinay, L., Botterill, D., Hilke, S. (2015): Politics and sustainable tourism: The case of Cyprus, Tourism Management, 47, 181.
} 
$\mathrm{H} 2 \mathrm{a}$ - Agrotourism brings appropriate benefits for municipalities and population.

H3 - The development of agrotourism affects the environment.

$\mathrm{H} 3 \mathrm{a}$ - The development of agrotourism has positive effects.

$\mathrm{H} 3 \mathrm{~b}$ - The development of agrotourism has corresponding negative effects.

$\mathrm{H} 4$ - The local population has an awareness of the sustainable development of tourism.

H4a - Municipalities have developed sustainable development strategies.

\section{Methodology of research}

The research was carried out on the territory of Middle Banat District in the following five municipalities: Zrenjanin, Žitište, Nova Crnja, Novi Bečej, Sečanj, during May 2017. The locals of particular structure $(\mathrm{N}=118$; gender, education, age, municipality) were included in the research. There were examined two categories of population: employees of travel agencies in given municipalities and administrative workers. For the verification of the hypothesis, the Descriptive Statistics and the Correlation Test were implemented. The indicators were explained in the analysis, and the standardization of the variables was performed: Gender: 1 = male gender; $2=$ female sex. Education: $1=$ secondary education; 2 = high professional education; 3 = faculty; $4=$ elementary school. City: 1 = Žitiste; 2 = Zrenjanin; 3 = New Crnja; $4=$ Novi Bečej; $5=$ Sečanj. The following questions were taken for the analysis:

1. Has agrotourism been developed sufficiently in your municipality? - mark Q1 (1 = yes; 2 = no).

2. Does agrotourism represent a developmental opportunity? - mark Q2 (1 = yes; $2=$ no).

3. What would the municipality gain by agrotourism development? - mark Q3 (1 = increase of standard, 2 = new jobs, 3 = improvement of quality of life, 4 = animation of free capital for investment, 5 = improvement of educational level of population).

4. Does agrotourism affect the state of the environment? - mark Q4 (1 = yes; 2 = no).

5. What are the positive effects of the development of agrotourism on the environment?

- mark Q5 (1 = restoration of old buildings and old parts of the settlement, 2 = building awareness of the importance of the environment, $3=$ planning of space design for the needs of tourists).

6. What are the negative impacts of the development of agrotourism on the environment?

- mark Q6 (1 = tourists' vandalism at the places of residence or visit; $2=$ 
inadequate occupancy due to excessive concentration of tourist facilities and the facilities in the function of tourism; 3 = destruction of hunting game).

7. Do you know what sustainable development is?

- mark Q7 (1 = yes; 2 = no).

8. Does your municipality have an adopted sustainable development strategy? - mark Q8 (1 = yes; 2 = no; 3 = do not know).

\section{Results and discussion}

The mean half of respondents was 1.57 , which indicates the equal representation of males and females in the study. The value of the standard deviation is 0.497 , and the variance 0.248 . An arithmetic mean for the age of the respondents is 38.95 years, with the standard deviation 13,574 , and variance 184,254 . The arithmetic mean of the respondents' level of qualification is 1.56 , and one can conclude that the majority of them are with a high school education. The standard deviation is 1.017, and the variance 1.035 .

Table 2. Descriptive analysis of the respondents by gender, age and education structure

\begin{tabular}{|l|c|c|c|c|}
\hline & $\mathbf{N}$ & Mean & Std. Deviation & Variance \\
\hline Gender & 118 & 1,57 &, 497 &, 248 \\
\hline Age & 118 & 38,95 & 13,574 & 184,254 \\
\hline Education & 118 & 1,56 & 1,017 & 1,035 \\
\hline Valid N (listwise) & 118 & & & \\
\hline
\end{tabular}

Source: the authors reached this conclusion based on the research

Table 3. Test Correlation

\begin{tabular}{|c|l|c|c|c|c|c|c|c|c|}
\hline \multicolumn{2}{|c|}{} & Q1 & Q2 & Q3 & Q4 & Q5? & Q6 & Q7 & Q8 \\
\hline \multirow{4}{*}{ Gender } & Pearson Correlation &,- 143 &, $228^{*}$ &,- 138 &, 149 &, 032 &, 056 &, 086 &, 118 \\
\cline { 2 - 10 } & Sig. (2-tailed) &, 123 &, 013 &, 137 &, 106 &, 731 &, 547 &, 355 &, 204 \\
\cline { 2 - 10 } & N & 118 & 118 & 118 & 118 & 118 & 118 & 118 & 118 \\
\hline \multirow{4}{*}{ Age } & Pearson Correlation &, 066 &, 031 &,- 067 &,- 138 &, 042 &, 146 &, 117 &,- 117 \\
\cline { 2 - 10 } & Sig. (2-tailed) &, 475 &, 735 &, 469 &, 135 &, 648 &, 116 &, 207 &, 209 \\
\cline { 2 - 9 } & N & 118 & 118 & 118 & 118 & 118 & 118 & 118 & 118 \\
\hline
\end{tabular}


Milutin Mrkša, Tamara Gajić, Aleksandra Vujko

\begin{tabular}{|c|l|c|c|c|c|c|c|c|c|}
\hline \multirow{4}{*}{ Education } & Pearson Correlation &, 108 &, 012 &,- 090 &, 100 &, 110 &, 137 &,- 034 &,$- 222^{*}$ \\
\cline { 2 - 10 } & Sig. (2-tailed) &, 245 &, 898 &, 331 &, 284 &, 236 &, 138 &, 716 &, 016 \\
\cline { 2 - 10 } & $\mathrm{N}$ & 118 & 118 & 118 & 118 & 118 & 118 & 118 & 118 \\
\hline \multirow{5}{*}{ Place } & Pearson Correlation &,$- 205^{*}$ &,$- 295^{* *}$ &,- 086 &,- 080 &,$- 192^{*}$ &,- 042 &, 063 &,- 141 \\
\cline { 2 - 10 } & Sig. (2-tailed) &, 026 &, 001 &, 352 &, 389 &, 038 &, 652 &, 497 &, 127 \\
\cline { 2 - 10 } & $\mathrm{N}$ & 118 & 118 & 118 & 118 & 118 & 118 & 118 & 118 \\
\hline
\end{tabular}

Based on the obtained results the dependence of the answers on the questions and sex, age, education and places of residence was examined:

- Gender: It has been found that the gender of the respondents had very little influence on the responses, which shows the low value of Pearson's coefficient $(0<0.3)$, which is summarized in terms of questions 0.143 , $0.228,0.138 ; 0.149 ; 0.032 ; 0.056 ; 0.086 ; 0.118$.

- Age: It was found that the age of the respondents had very little influence on the response, which shows the low value of Pearson's coefficient $(0<0.3)$ which is summarized in terms of questions $0.066,0.031,0.067$; $0.138 ; 0.042 ; 0.146 ; 0.117 ; 0.117$.

- Education: It has been established that the expert's assessment of the respondents has very little influence on the answer, which shows the low value of Pearson's coefficient $(0<0.3)$, which is summarized in terms of questions $0.108,0.012,0.090 ; 0.11 ; 0.137 ; 0.034 ; 0.22$.

- City: It has been found that the place of residence of the respondents had very little influence on the response, which shows the low value of Pearson's coefficient $(0<0.3)$ 0.026, 0.295, 0.086; 0.08; 0.192; 0.042; 0.063; 0.141 .

By examining the correlation between the mentioned issues and the structure of the population, it is not possible to find dependence. The Pearson coefficient values for all parameters are below 0.3 , indicating that there is a very lowintensity dependence. This can be a worrying fact, because the whole viewpoint has no clear issue of the importance of tourism for its municipality regardless of sex, age, education and the place they are from. Also, the population lacked education on tourism potentials, sustainable development, and environmental protection. With this information negating the starting hypothesis $\mathrm{H} 0$, there is a significant statistical difference in the perception of the population of the development and importance of tourism in relation to demographic segments (gender, age, education).

The highest percentage of local population points out that agrotourism has not been developed sufficiently in their municipality. The value of the arithmetic mean is 1.92 , while the value of the standard deviation is 0.28 . The hypothesis $\mathrm{H} 1$ is confirmed. The value of the arithmetic mean for the issue of tourism as 
a development opportunity is 1.20 , while the value of the standard deviation is 0.40 . This leads us to a conclusion that the population believes that tourism definitely represents a developmental opportunity for their municipalities ( $\mathrm{H} 2+)$. Most respondents point out that the development of tourism will lead to the creation of new jobs and improvement of living standard (an arithmetic mean value is 2.53 , while the value of standard deviation is 1.27 ), which indicates that $\mathrm{H} 2 \mathrm{a}$ subhypothesis is confirmed, as the local population points out that tourism brings certain benefits.

The value of the arithmetic mean for the issue of the impact of the development of agri tourism on the state of the environment is 1.16 , while the value of the standard deviation is 0.37 . All respondents believe that tourism has a great impact on the state of the environment (H3+). The $\mathrm{H} 3 \mathrm{a}$ is that tourism has positive effects on the environment, as the data indicate that the population is aware of it (the value of the arithmetic mean is 1.80 , while the value of the standard deviation is 0.87). For the question of the negative impacts of tourism on the environment, the value of the arithmetic mean is 1.58 , while the value of the standard deviation is 0.73 . That gave the conclusion that tourism could have an adverse effect on the environment, because there is a fear of tourist vandalism in places of residence or visit, as well as inadequate occupancy due to excessive concentration of tourist capacities and facilities in the function of tourism $(\mathrm{H} 3 \mathrm{~b}+)$.

On average, respondents did not know what sustainable development exactly meant and represented, which can be a major barrier to further tourism development, and this data is negated by the $\mathrm{H} 4$ hypothesis (the value of the arithmetic mean is 1.64 , while the value of the standard deviation is 0.48 ). The value of the arithmetic mean for the question of whether the municipality has a strategy for the development of sustainable tourism is 2.73 , while the value of the standard deviation is 0.61 . The population was not informed about any adopted sustainable development strategies in their places of residence (H4a -).

\section{Conclusion}

To sum up, tourism is a very important branch of the economy that implies the development of other sectors of the economy, and together with them enters the world and the European market. The contribution of tourism to the economic development of an area is manifested in its impact on investment, income or employment, causing them to rise, and as a rule, the rise in the standard of living of the individual and the community in which it takes place. There are also negative sides of tourism. They manifest themselves not only in the economic domain, but also in the socio-cultural, demographic, cultural and ecological domain.

However, the tourism of Serbia, and therefore of Middle Banat, has never had a primary role in economic and social development. The greatest factor 
of stagnation and the generally slow development of tourism is an unfavorable political and economic situation in which the state was at the end of the 20th century. However, the data show that the situation has been changing in a positive direction, but that it is not yet at an enviable level. Local citizens have a decisive role in the development of tourism, and sometimes they can be a limiting factor in its expansion. In the world, this is an acute topic of research, and on the basis of this data, it is perceived that tourism, due to its positive economic impact, is accepted in a large number of cases. Different attitudes of the local population towards tourists and their preferences primarily depend on whether the inhabitants depend on the revenues generated by tourism. Changes to the local population caused by tourism development occur continuously, and can be both positive (employment opportunities, infrastructure improvements, etc.) and negative (traffic jams, crime, exceeding acceptance potential, etc.). There are various relationships between the tourists and the local inhabitants of the destination that are caused by different levels of participation in the daily activities.

There are also situations where the population does not accept its development, because they see no benefit from it, apart from the commercialization of other culture and spreading of negative effects on the local population. Where tourism is not recognized as a positive economic sector, the society does not approve its expansionary development ${ }^{25}$. In the process of tourism realization, a series of effects that are most often visible in the environment are generated, i.e. on natural and built resources which involves the term environment itself. The main reasons for the impact of tourism on the environment are that tourist destinations are exposed to more tourist arrivals or to a larger number of people, which requires taking organizational and technical measures in order to realize tourism. The harmful effect on the environment in particular reduces the value of nature as an attraction and a place for rest. The difference in the attractiveness of the natural environment in the starting point and tourist destination of the tourists is reduced due to the environmental degradation by improper construction, noise pollution or water pollution. Community support for the development of tourism is needed in achieving commercial, sociocultural, physiological, political and economic sustainability of the industry. Therefore, it is considered that the local population is a key stakeholder in the development of tourism in a particular location. As previously mentioned in the paper, tourism can create positive and negative impacts on the inhabitants, and it can often be hard to recognize the real impact ${ }^{26,27}$.

\footnotetext{
25 Sharpley, R. (2014): Host perceptions of tourism: A review of the research. Tourism Management, 42, 41.

26 Teye, V., Sonmez, S. F., Sirakaya, E. (2002): Residents' attitudes toward tourism development. Annals of Tourism Research, 29(3), 670.

27 Vargas, A., Oom do Valle, P., Da Costa, J., Albino, S. (2015): Residents' attitude and level of destination development: an international comparison, Tourism Management, 48(3), 200.
} 
After reviewing a large number of secondary documentation and papers on the current topic, the authors carried out an investigation of the opinion of the local population about the significance of the development of agro tourism. The research was carried out in five municipalities of Middle Banat, during May 2017. The established hypotheses and the data that confirm them undoubtedly indicate the poor development of this activity in Middle Banat, as well as insufficient general information of the local population about its significance.

Table 4. Hypothesis

\begin{tabular}{|c|c|c|}
\hline Hypotheses & $\begin{array}{c}\text { Confirmed } \\
+\end{array}$ & $\begin{array}{c}\text { Rejected } \\
-\end{array}$ \\
\hline $\begin{array}{l}\text { H0 - there is a significant statistical difference in the perception } \\
\text { of the population about the development and importance } \\
\text { of tourism in relation to demographic segments (gender, } \\
\text { age, education). }\end{array}$ & & HO \\
\hline H1 - Agrotourism has not been developed sufficiently. & $\mathrm{H} 1$ & \\
\hline $\begin{array}{l}\mathrm{H} 2 \text { - Agrotourism represents a developmental opportunity in } \\
\text { the investigated municipalities. }\end{array}$ & $\mathrm{H} 2$ & \\
\hline $\begin{array}{l}\mathrm{H} 2 \mathrm{a} \text { - Agrotourism brings appropriate benefits for municipalities } \\
\text { and population. }\end{array}$ & $\mathrm{H} 2 \mathrm{a}$ & \\
\hline H3 - The development of agrotourism affects the environment. & $\mathrm{H} 3$ & \\
\hline H3a - The development of agrotourism has positive effects. & $\mathrm{H} 3 \mathrm{a}$ & \\
\hline $\begin{array}{l}\text { H3b - The development of agrotourism has corresponding } \\
\text { negative effects. }\end{array}$ & $\mathrm{H} 3 \mathrm{~b}$ & \\
\hline $\begin{array}{l}\mathrm{H} 4 \text { - The local population has an awareness of the sustainable } \\
\text { development of tourism. }\end{array}$ & & $\mathrm{H} 4$ \\
\hline $\begin{array}{l}\text { H4a - Municipalities have developed sustainable development } \\
\text { strategies. }\end{array}$ & & $\mathrm{H} 4 \mathrm{a}$ \\
\hline
\end{tabular}

In the last decade of the 20th century, tourism showed that it achieved a leading position as a world economy in relation to other branches of the economy. Experts agree that tourism is the fastest growing industry in the world. It is also an industry that is very difficult to control and regulate. It assumes a significant responsibility in relation to the economic, social, cultural and natural environment. 


\section{Literature}

- Almeida, F., Balbuena, A., Corte s, R. (2015): Residents' attitudes towards the impacts of tourism, Tourism Management Perspectives, 13(1), 33-40.

- Andriotis, K., (2006): Hosts, Guests and Politics. Annals of Tourism Research, 33(4), 1079-1098.

- $\quad$ Andereck, K., Valentine, K., Knopf, R., Vogt, C. (2005): Residents' perceptions of community tourism impacts, Annals of Tourism Research, 32(4), 1056-1076.

- Balaguer, J., Cantavella-Jorda, M. (2002): Tourism as a longrun economic growth factor the Spanish case, Applied Economics, 34(7), 877-884.

- Chen, F., Tian, L., (2015): Comparative study on residents' perceptions of follow-up impacts of the 2008 Olympics, Tourism Management, 51, 263-281.

- Farmaki, A., Altinay, L., Botterill, D., Hilke, S. (2015): Politics and sustainable tourism: The case of Cyprus, Tourism Management, 47, 178-190.

- Gajić, T. (2010): Tourism in the function of intensification receptive and emissive regions - example of South Bačka region, Industry, 38(3), 139-154.

- Gursoy, D., Jurowski, C., Uysal, M. (2002): Resident attitudes. A structural modeling approach, Annals of Tourism Research, 29(1), 79-105.

- Huh, C., Vogt, C. A. (2008): Changes in residents' attitudes toward tourism over time: a cohort analytical approach, Journal of Travel Research, 46, 446-455.

- Hung, K., Sirakaya-Turk, E., Ingram, L. J. (2011): Testing the efficacy of an integrative model for community participation, Journal of Travel Research, 50(3), 276-288 .

- Kim, K., Uysal, M., Sirgy, M. (2013): How does tourism in a community impact the quality of life of community residents? Tourism Management, 36, 527-540.

- Ko, D. W., Stewart, W. P. (2002): A structural equation model of residents' attitudes for tourism development, Tourism Management, 23, 521-530.

- Mason, P., Cheyne, J. (2000): Residents attitudes to proposed tourism development, Annals of Tourism Research, 27(2), 391-411.

- Nunkoo, R., Gursoy, D. (2012): Residents' support for tourism an identity perspective, Annals of Tourism Research, 39(1), 243-268.

- Petrović, M., Blešić, I., Vujko, A., Gajić, T. (2017): The role of agrotourism impact in local community in a transition society - a report from Serbia, Transylvanian Review of Administrative Structure Sciences. 50(1), 146-163.

- Prayag, G., Hosany, S., Nunkoo, R., Alders, T. (2013): London residents' support for the 2012 Olympic games: the mediating effect of overall attitude, Tourism Management, 36, 629-640.

- Sharpley, R. (2014): Host perceptions of tourism: A review of the research, Tourism Management, 42, 37-49

- Sheldon, P. J., Abenoja, T. (2001): Resident attitudes in a mature destination: the case of Waikiki, Tourism Management, 22, 435-443. 
- Teye, V., Sonmez, S. F., Sirakaya, E. (2002): Residents' attitudes toward tourism development, Annals of Tourism Research, 29(3), 668-688.

- Tosun, C. (2006): Expected nature of community participation in tourism development, Tourism Management, 27(3), 493-504.

- Vargas, A., Oom do Valle, P., Da Costa, J., Albino, S. (2015): Residents' attitude and level of destination development: an international comparison, Tourism Management, 48(3), 199-210.

- Vujko, A., Gajić, T. (2014): Opportunities for tourism developmentand cooperation in the region by improving quality supply - The Cycle Danube Route - Case study, Economic Research, 27(1), 847-860.

- Vujko, A., Petrović, M., Dragosavac, M., Gajić, T., (2016): Differences and similarities among rural tourism in Slovenia and Serbia - perceptions of local tourism workers, Ekonomika poljoprivrede, 4/2016, 1459-1469.

- Waligo, V. M., Clarke, J., Hawkins, R. (2013): Implementing sustainable tourism: A multi-stakeholder involvement management framework, Tourism Management, 36, 432, 353.

- Woods, N. (2003): The United States and the international financial institutions. In R. Foot, N. MacFarlane, \& M. Mastanduno (Eds.), US hegemony and international organizations (pp. 92-114). Oxford: Oxford University Press.

- Zhang, Y., Cole, S. T., Chancellor, C. H. (2013): Residents' preferences for involvement in tourism development and influences from individual profiles, Tourism Planning \& Development, 10(3), 267-284. 


\section{ANALIZA RAZVOJA I ZNAČAJA AGROTURIZMA KROZ PERCEPCIJU LOKALNOG STANOVNIŠTVA U SREDNJEM BANATU}

Uopšteno govoreći, turizam kao privredna grana nikada nije imao zavidnu poziciju na tržištu u poređenju sa drugim granama privrede. Srbija je zemlja ruralnog prostora, ali ovaj oblik turizma nije u ekspanziji. U stvaranju lošeg stanja turističke aktivnosti, odlučujuću ulogu je imala loša ekonomska i politička situacija u poslednjim godinama 20. veka. Autori rada sproveli su terensko istraživanje na području Srednjeg Banata kako bi istražili percepciju lokalnog stanovništva o značaju razvoja ove aktivnosti. Istraživanje je sprovedeno u maju 2017. godine u pet opština Srednjeg Banata, a rezultati jasno ukazuju na lošu situaciju o svesti ispitanika o značaju razvoja agro turizma, iako postoje stvarni preduslovi za masovniji razvoj Ove delatnosti.

Ključne reči: agroturizam, lokalno stanovništvo, održivi razvoj, Srednji Banat 